\title{
振幅変調 DLに関する基礎的実験
}

\section{大和田健次郎 古賀慶次郎（鹿大）}

序文

recruitment phenomen をしらべるBalance test と DL test の間に本質的な差異がありは しないかといら疑問のもとに先に我々は二音比 較法と変調法のちがいを検討し発表した。この 疑問はまだ解決されていない。今回は変調 DL の本態をなす, Beat 感或は音の強弱の変動を 検知する様態を明かにするため，今までしらべ られていない低い周波数の振巾変調を行い次の 実験結果を得た。

\section{実 験 概 要}

$1 \mathrm{KC}$ の純音を振巾変調するが，振巾変調の条 件は矩形波変調と正弦波変調で, その変調周波 数はそれぞれ $0.5 \mathrm{c} / \mathrm{s}, 0.3 \mathrm{c} / \mathrm{s},-0.25 \mathrm{c} / \mathrm{s}, 0.16 \mathrm{c} / \mathrm{s}$ である。この条件で DL 值を正常人四名につい てもとめた值を検討した。

\section{実 験 装 置}

発振器 (1 KC 純音) からレ:シーバまでのブロ 、ックダイヤグラムは図 1 の通り，変調は矩形波 は stimulator の電圧を利用し $0.5 \mathrm{c} / \mathrm{s}$ と $0.3 \mathrm{c} / \mathrm{s}$ は automatic に $0.25 \mathrm{c} / \mathrm{s}$ と $0.16 \mathrm{c} / \mathrm{s}$ はスイッチ を手動的に用いて行つた。stimulator の電圧は 勿論 1 図の AMPに含まれる図 3 の $6 \mathrm{AS} 6$ の サプレッサーグリッドに作用せしめる。正弦波 変調は図 2 の如き位相発振器を用い生じた正弦 波電圧を 6 A S 6 に作用せしめる。

被検者 正常の耳 4 耳である。

成績

図 4 の如く矩形波変調と正弦波変調の間に著 明なちがいのあることがわかる。即ち，

i）矩形波変調では D L 值は周波数の如何に 拘らす殆ど同じ值であるが，正弦波変調では変 調周波数が小となる程 D L 值は大となつてい る。この関係は図4に現われているが，この関 係を更にはつきり明示したのが図 $5 \mathrm{a}, \mathrm{b}$ ，c で ある。猶図 4，5で実線又は点線で示したりは 平均值である。 ii）個体差をみると（図 4) 矩形波では差が 少く, 正弦波では差が大である。即ち正弦波変 調の方が検知が困難であることがわかる。

iii）以上のことから音の強弱の変動感を起さ せる因子は音が急速に強くなること，或は弱く なることにかかつている。而も我々の実験では 音が強くなることの方が弱くなることより検知 が容易である。（図 5) 即ちこの実験では梯形の 波形で変調を行つて，音の強さの強くなる場合 と弱くなる場合の D L 值をもとめて比較した。

iv）然らばどの程度以上の速さで音が強くな るとき，それを検知出来るか。図 $5 \mathrm{c}$ 汇閾値上 $30 \mathrm{db}$ の正統波の各変調周波数のD L 值を示して あるが，この值より，検知出来る音の強さの変 動速度の限界を計算すると，

変調周波数…….... $\mathrm{a} \mathrm{c} / \mathrm{s}$

各周波数の D L值 $\cdots \mathrm{b}$ db とすれば

$1 \mathrm{db}$ 強さが強くなる変動速度

$$
\mathrm{C}=\frac{1}{2 \mathrm{ab}} \mathrm{sec} / \mathrm{db}
$$

従つて正統波変調 $0.5 \mathrm{c} / \mathrm{s}, 0.3 \mathrm{c} / \mathrm{s}, 0.25 \mathrm{c} / \mathrm{s}$ の何 れの場合も $\mathrm{C}=1.0 \mathrm{sec} / \mathrm{db}, 0.16 \mathrm{c} / \mathrm{s}$ では $\mathrm{C}=0.7$ $\mathrm{sec} / \mathrm{db}$ で閾值上 $30 \mathrm{db}$ の強さでは音の強さの変 動速度が $1 \mathrm{db}$ 当り略 $1 \mathrm{sec}$ より小なる值のとき は検知されることが判る。

考案及び結語

以上の結果より D L值を決定する最も重要な 要素は，変動が頻回におこるかどうかというこ とより，変動の速度が問題である。その速度の 検知限界は $1 \mathrm{sec} / \mathrm{db}$ で，この值が $0.5 \mathrm{c} / \mathrm{s}$ 変調の $\mathrm{D}$ L值 $1 \mathrm{db}$ の変動速度に当る。又先に発表した 我々の研究により $6 \mathrm{c} / \mathrm{s}$ より $0.5 \mathrm{c} / \mathrm{s}$ までの変調で は矩形波でも正統波でも D L 值に差がなけこと を示したが，今回我々が明かにした矩形波 D L がす心゙て略 $1 \mathrm{db}$ の D Lを示すことを考え合わせ

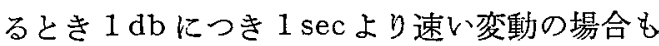
D L值は大体 $1 \mathrm{db}$ を示すことが明らかになり， $6 \mathrm{c} / \mathrm{s}$ より $0.5 \mathrm{c} / \mathrm{s}$ 変調までの D L值が一致するこ とが理論的にも証明される。 

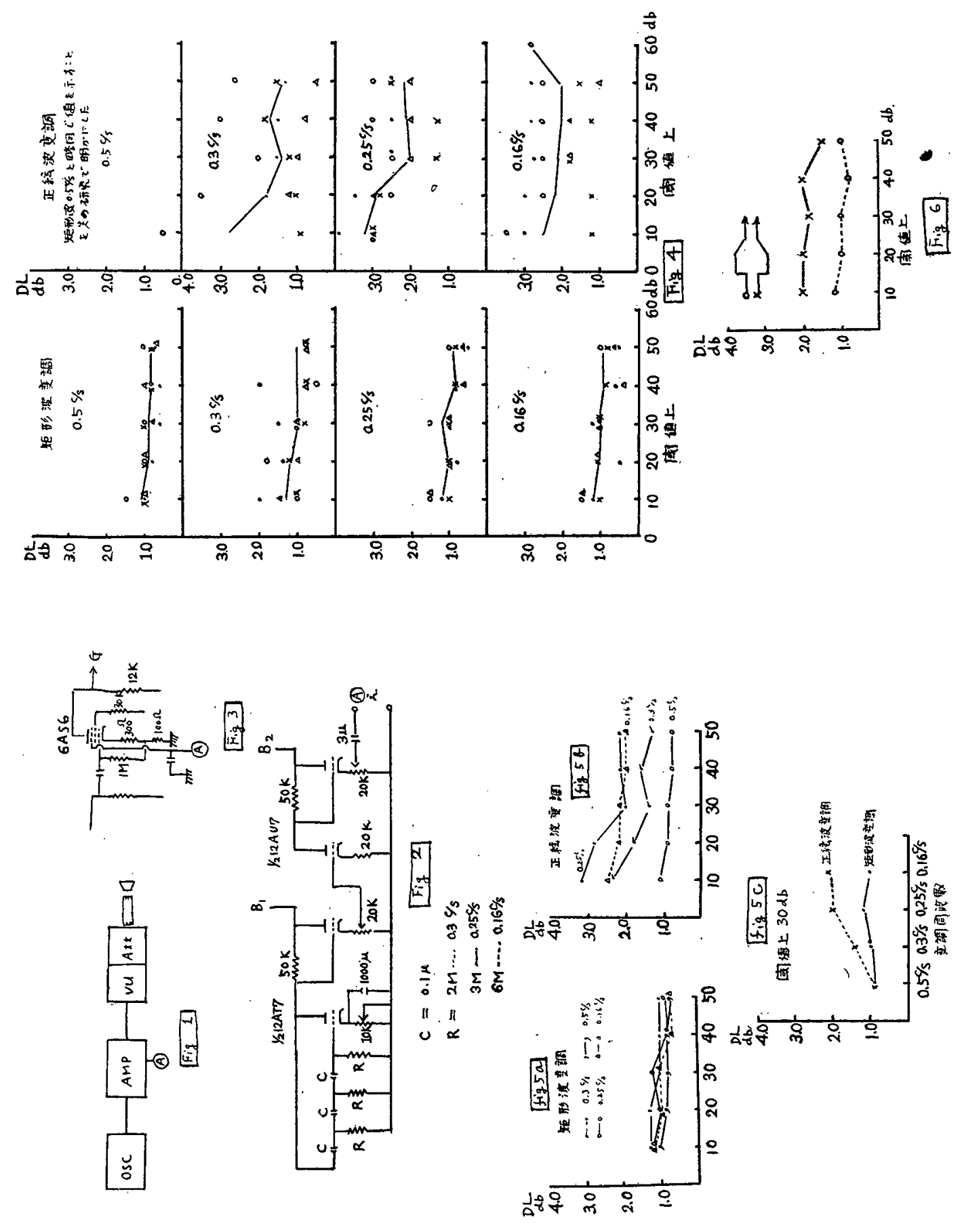